\title{
The correct name of Aloe plicatilis, the fan aloe, in the genus Kumara (Asphodelaceae: Alooideae), again
}

\author{
Ronell R. Klopper ${ }^{1,2}$, Gideon F. Smith ${ }^{1,2,3}$ \& Abraham E. van Wyk ${ }^{2}$ \\ 1 Biosystematics Research and Biodiversity Collections Division, South African National Biodiversity In- \\ stitute, Private Bag X101, Pretoria 0001, South Africa. (email: r.klopper@sanbi.org.za; \\ g.smith@sanbi.org.za) \\ 2 H.G.W.J. Schweickerdt Herbarium, Department of Plant Science, University of Pretoria, Pretoria, 0002, \\ South Africa. (email: braam.vanwyk@up.ac.za) \\ 3 Centre for Functional Ecology, Departamento de Ciências da Vida, Universidade de Coimbra, 3001-455 \\ Coimbra, Portugal
}

Summary: The combination Kumara plicatilis (L.) Klopper \& Gideon F.Sm. recently published for the fan aloe [Aloe plicatilis (L.) Burm.f.], is a synonym of Kumara plicatilis (L.) G.D.Rowley, the latter having priority due to earlier valid publication.

Zusammenfassung: Die kürzlich für die "fan aloe" [Aloe plicatilis (L.) Burm. f.] publizierte Kombination Kumara plicatilis (L.) Klopper \& Gideon F.Sm. ist ein Synonym von Kumara plicatilis (L.) G.D.Rowley, welche Prioriät aufgrund der gültigen früheren Publikation hat.

\section{Introduction}

Publication of Grace et al. (2013) generated considerable interest among succulent plant enthusiasts as it initiated the deconstruction of the well-known genus Aloe L. (Asphodelaceae: Alooideae, alternatively Xanthorrhoeaceae: Asphodeloideae), which has remained comparatively unfettered for more than 150 years. When the genus Kumara Medikus (1786: 69) is resurrected for the fan aloe [Aloe plicatilis (L.) Burm.f.], Klopper et al. (2013 [3 July 2013]) showed that the correct specific epithet to use is plicatilis, and not disticha, and corrected the name to Kumara plicatilis.

However, this combination was earlier made by Rowley (2013 [9 April 2013]). Kumara plicatilis (L.) Klopper \& Gideon F.Sm. is therefore a superfluous name and synonym of Kumara plicatilis (L.) G.D.Rowley, the correct name of the fan aloe when placed in Kumara.

This is not the first time that a new combination for this aloe was published by separate authors in close succession. As explained by Klopper et al. (2013), the correct author citation for Aloe plicatilis is (L.) Burm.f. and not (L.) Mill. as it was given by Rowley (2013) and used historically. This combination was first published by Burman in Prodromus Florae Capensis (1 March to 6 April 1768). The combination made by Miller in The Gardener's Dictionary (16 April 1768) is thus a superfluous name.

\section{Taxonomy}

Kumara plicatilis (L.) G.D.Rowley in Alsterworthia International Special Issue No.10: 3 (9 April 2013). Aloe disticha var. plicatilis L., Species Plantarum: 321 (1753). Aloe plicatilis (L.) Burm.f., Flora Indica, Prodromus Florae Capensis: 10 (1 March-6 April 1768). Aloe plicatilis (L.) Mill., nom. superfl., The Gardener's Dictionary 8: 7 (16 April 1768). Aloe tripetala Medik., nom. superfl., Botanische Beobachtungen des Jahres 1783: 55 (1783). Kumara disticha sensu Medikus, nom. superfl., Theodora Speciosa: 70, t.4 (1786). Rhipidodendrum distichum (Medik.) Willd., Magazin für die neuesten Entdeckungen in der gesammten Naturkunde der Gesellschaft Naturforschender Freunde zu Berlin 5: 165 (1811). Rhipidodendrum plicatile (L.) Haw., Revisiones plantarum succulentarum: 45 (1821). Kumara plicatilis (L.) Klopper \& Gideon F.Sm., nom. superfl., Phytotaxa 115: 59 (3 July 2013). Lectotype: Aloe africana arborescens montana non spinosa, folio longissimo plicatili, flore rubro [Commelijn (1701: 5, t.3); designated by Wijnands (1983: 125)].

Aloe linguaeformis L.f., nom. illegit., Supplementum Plantarum: 206 (1782). Type: Cape of Good Hope, Thunberg 8590 (UPS, holo.)

Aloe lingua Thunb., Dissertatio botanica de Aloë: 7 (1785). Type: South Africa, no precise locality, Thunberg 8590 (UPS, holo.).

Aloe flabelliformis Salisb., Prodromus stirpium in horto ad Chapel Allerton vigentium: 147 (1796). Type: not cited. 


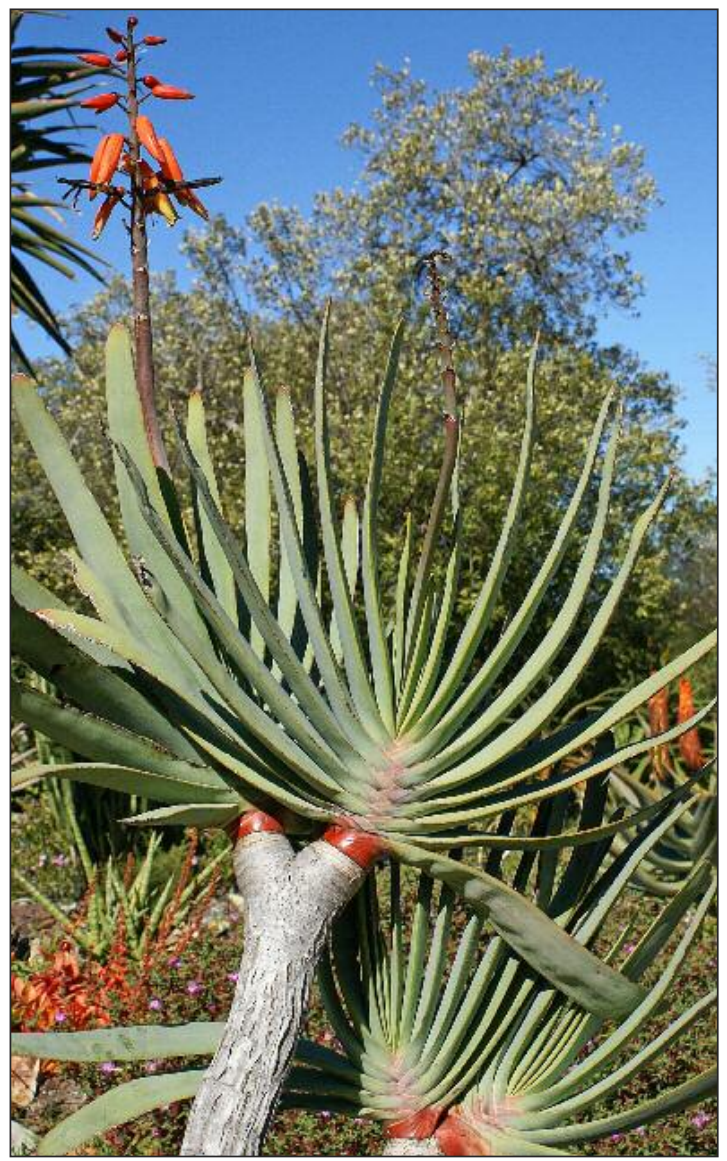

Figure 1. The leaves of Kumara plicatilis, which is endemic to Mediterranean parts of South Africa's Western Cape Province, are arranged in the shape of a fan. Photograph: A.W. Klopper.

Aloe plicatilis (L.) Mill. var. major Salm-Dyck, Verzeichniss der verschiedenen Arten und Abarten des Geschlechts Aloe: 30, 63 (1817). Type: not cited.

\section{References}

Commelijn, J. (1701). Horti medici Amstelaedamensis rariorum plantarum descriptio et icons 2. Blaeu, Amsterdam

Grace, O.M., Klopper, R.R., Smith, G.F., Crouch, N.R., Figueiredo, E., Rønsted, N. \& VAn WyK, A.E. (2013). A revised generic classification for Aloe (Xanthorrhoeaceae subfam. Asphodeloideae). Phytotaxa 76(1): 7-14.

http://dx.doi.org/10.11646/phyto taxa.76.1.22013

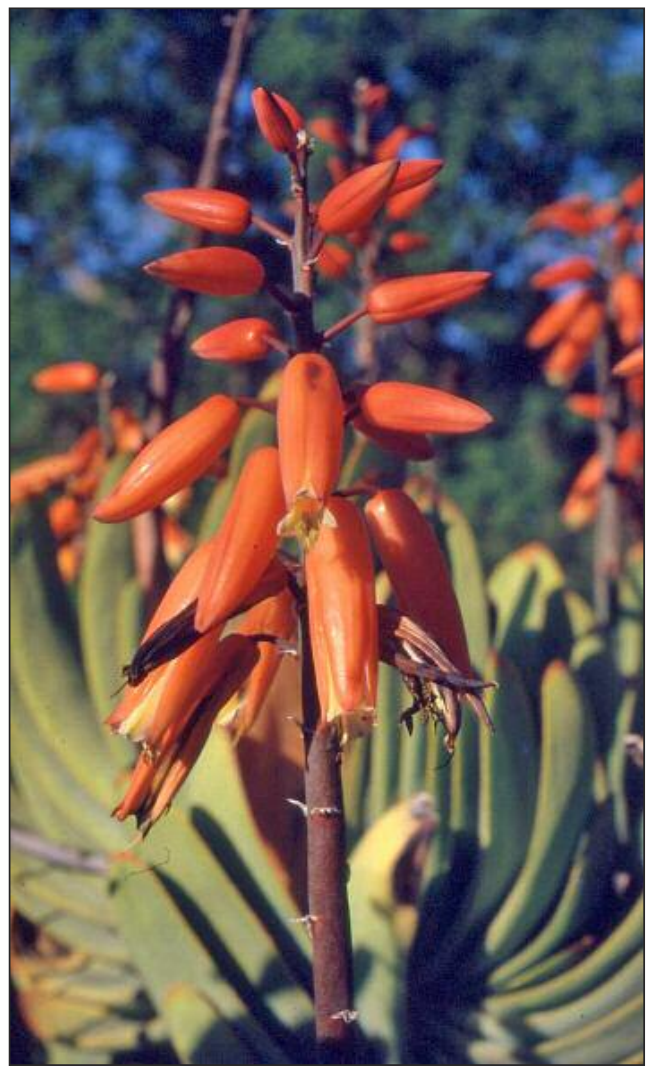

Figure 2. The cigar-shaped flowers of the fan aloe, Kumara plicatilis, are bright red, with the flared tips infused with yellow.

Photograph: G. Nichols.

Klopper, R.R, Smith, G.F. \& VAn WyK, A.E. (2013). The correct name of Aloe plicatilis in Kumara (Xanthorrhoeaceae: Asphodeloideae). Phytotaxa 115(2): 59-60.

http://dx.doi.org/10.11646/phytotaxa.115.2.5

Medikus, F.K. (1786). Theodora speciosa: ein neues Pflanzen Geschlecht. Hof- und Akademische Buchhandlung, Mannheim, 116 pp.

Rowley, G. (2013). Generic concepts in the Alooideae. Part 3 - The phylogenetic story. Alsterworthia International Special Issue No. 10: 3-6.

WiJnands, D.O. (1983). The Botany of the Commelins: A Taxonomical, Nomenclatural and Historical Account of the Plants Depicted in the Moninckx Atlas and the Four Books by Jan and Caspar Commelin on the Plants in the Hortus Medicus Amstelodamensis, 1682-1710. Taylor \& Francis, Abingdon. 